\title{
Information and communication technology related needs of college and university students with disabilities
}

\author{
Catherine S. Fichten*, Jennison V. Asuncion, Joan Wolforth, Maria Barile,
} Jillian Budd, Natalie Martiniello and Rhonda Amsel Adaptech Research Network, Dawson College, Jewish General Hospital, McGill University,
Québec, Canada

(Received 27 April 2012; final version received 24 October 2012)

Purpose: To explore variables related to how well the information and communication technologies (ICTs) related needs of students with different disabilities are being met on campus at institutions of higher education, at home and in e-learning contexts. We also explore the disciplines and programmes pursued by students with different disabilities and the specialised ICTs they use.

Method: A total of 1,354 Canadian university and junior/community college students with various disabilities completed the POSITIVES Scale.

Results: Post-secondary students often have several disabilities which may affect how easily they can use ICTs. Students' disabilities also influence the specialised ICTs they use and how well their ICT-related needs are being met. While the findings indicate that, overall, students' ICT-related needs are generally well met, the results also show that these are better met on campus than at home, and at colleges than at universities. This is not related to institution size or to students' disciplines.

Conclusions: Our results show more favourable than unfavourable findings. Nevertheless, there are concerns around the availability of computers with adaptive software/hardware in specialised laboratories as well as with institutional ICT loan programmes; funding for ICTs for personal use; training, both on and off campus; and technical support off campus.

Keywords: college university students; disabilities; POSITIVES Scale; ICT needs; e-learning

University and junior/community college students with disabilities have the same information and communication technology (ICT) related needs as other students (Seale, Draffan, and Wald 2008). They need to work in computer and smart-board equipped classrooms and laboratories, do assignments and access the Internet on campus between classes, use ICTs from home, engage in mobile and social networking applications and access the institution's interactive online services, including e-learning ICTs used by professors in their teaching (CDW-G 2011).

All students, including students with disabilities, need to use a variety of general purpose software such as Microsoft Word, email programmes, as well as software related to their disciplines (e.g. statistical analyses, virtual science experiments, language tutorials). In addition to general purpose ICTs, however, many students

*Corresponding author. Email: catherine.fichten@mcgill.ca

RLT 2012. (C) 2012 C.S. Fichten et al. Research in Learning Technology is the journal of the Association for Learning 


\section{C.S. Fichten et al.}

with disabilities also need to obtain and learn to use adaptive software and/or hardware, which allows them to use such technologies effectively. Examples of difficulties include students with hearing impairments using uncaptioned educational video clips and recorded lectures. Students with mobility and neuromuscular impairments have ergonomic issues related to computer desk height and positioning. Many also need alternate input devices if they have difficulty using their hands or arms. Students with learning disabilities often need ICTs that help with reading, outlining and writing more effectively. Students with visual impairments, too, need to be able to read their textbooks and other types of course materials.

Post-secondary students must also adapt to the extensive e-learning used by faculty (Abrami et al. 2006). This includes PowerPoint in class, online discussions to further in-class dialogue and the full range of ICTs that professors use (Fichten 2009a). Students are expected to download materials from course websites, access course management systems such as Moodle and Blackboard, and engage in interactive online activities and study groups. Our research shows that while certain forms of e-learning have excellent accessibility, while others pose serious concerns for students with different disabilities (Fichten 2009b).

Although students were enthusiastic about the benefits of e-learning, they also indicated experiencing problems with these and most of which remained unresolved (Fichten 2009b). For example, students described technical difficulties using elearning and problems connecting to websites and course management systems. They also had problems downloading and opening files, with web pages that would not load, and with poor use of e-learning by professors, such as failure to put material onto the course website on time, incomplete online course notes and in-class PowerPoint presentations. Some websites were not compatible with screen-reading technologies, others had structures that made it difficult for students with learning disabilities to navigate and others still posed problems related to fixed colours and font sizes as well as online maps and images. Poor accessibility of audio and video materials were also noted when these were not captioned. The absence of description about what is going on in video clips caused accessibility problems for students with visual impairments. The same was true for online-videotaped lectures and multimedia materials. PowerPoint and data projection during lectures also caused accessibility problems for students, mainly for those with visual and hearing impairments. Another problem area relates to inaccessibility of course notes and materials in PDF, especially when professors use old annotated print materials that are difficult to render into electronic text that screen readers can handle. Students also identified lack of needed adaptive technologies on campus. This left them merely sitting in class while their peers engaged with the e-learning materials provided by the professor. The increased use of online and social media for teaching and learning also poses challenges (Boudreau 2011; Media Access Australia 2012).

Nevertheless, students with disabilities saw ICTs as tools for success (Fichten 2009 b). In this context, we need to stress that adaptations made by faculty and postsecondary institutions to assist students with disabilities can also be beneficial to non-disabled students. Recently, a trend has emerged towards the use of universal design in higher education. Proponents contend that instruction and learning products that are beneficial to students with disabilities are beneficial to all students (e.g. Burgstahler and Cory 2008).

At present, many students with different disabilities need specific types of adaptive technologies that allow them to access the ICTs they need. These 
technologies may be more readily available either on campus or at home. Therefore, in the present investigation we explored the types of adaptations used by students with different disabilities and how well students' ICT-related needs are being met on campus, at home and in e-learning contexts.

Students with disabilities are more likely to attend junior/community colleges than universities (Raue and Lewis 2011). These tend to be smaller than universities and may also have different policies and practices in place when it comes to ICTs and e-learning. Therefore, we examined whether students' ICT-related needs are better met at junior/community colleges or at universities and also whether the ICT-related needs of students are better met in larger or smaller institutions. To better understand their ICT-related needs, we also examined the programmes and disciplines pursued by students with different disabilities.

\section{Method}

\section{Participants}

A "convenience sample" of 1,354 students with various disabilities from 111 different Canadian universities and junior/community colleges completed a web-based questionnaire battery. Among the participants, 456 were male, 894 were female and 4 did not indicate their sex. Participants' mean age was 28.10 (standard deviation $=9.42$, range $=18-64$, median $=24)$. A total of 974 students $(72 \%)$ attended a university, and $368(27 \%)$ attended a junior/community college (12 failed to specify this). Participants attended college or university in all 10 of Canada's provinces and completed measures either in English $(n=1,213)$ or French $(n=141)$. Students' disabilities are presented in Table 1 . The largest number of students were pursuing an undergraduate degree $(54 \%)$ or a junior/community college certificate or diploma (21\%). The rest were pursuing a graduate degree or diploma $(13 \%)$, a university certificate or diploma $(8 \%)$ or another type of qualification $(2 \%)$.

\section{Measures}

Demographic questions

These included sex, age, post-secondary institution name, programme of studies pursued and students' disabilities. The information provided allowed us to determine institution size (full-time plus part-time enrolment).

\section{Disabilities}

We provided a list of 13 types of disabilities/impairments and asked students to selfselect as many as applied to them (see Table 1).

\section{Disciplines}

Students indicated, in an open-ended manner, the discipline that they were studying. These were classified into nine categories (see Table 2) in accordance with a discipline-coding manual (Martiniello et al. 2008). Mean inter-rater agreement was $88 \%$, and Cohen's kappa was 0.86 . 
Table 1. Age and disabilities of participants: single versus multiple disabilities.

\begin{tabular}{|c|c|c|c|c|c|c|c|}
\hline $\begin{array}{l}\text { 1,106 students with a single } \\
\text { disability/impairment }\end{array}$ & $\begin{array}{l}\text { Number } \\
\text { of students }\end{array}$ & Percent & $\begin{array}{l}\text { Mean } \\
\text { age }\end{array}$ & $\begin{array}{l}\text { 1,354 students with single or } \\
\text { multiple disabilities/ } \\
\text { impairments }\end{array}$ & $\begin{array}{l}\text { Number } \\
\text { reporting each } \\
\text { disability }\end{array}$ & Percent & $\begin{array}{l}\text { Mean } \\
\text { age }\end{array}$ \\
\hline Single disabilities/impairments & 894 & & & All participants reporting each disability ${ }^{\mathrm{a}}$ & & & \\
\hline Totally blind & 17 & 1 & 30.71 & Totally blind & 24 & 2 & 31.83 \\
\hline Low vision & 62 & 5 & 27.26 & Low vision & 116 & 9 & 31.24 \\
\hline Deaf & 14 & 1 & 27.36 & Deaf & 19 & 1 & 29.78 \\
\hline Hard of hearing & 43 & 3 & 26.58 & Hard of hearing & 92 & 7 & 29.22 \\
\hline Speech/communication impairment & 2 & $<1$ & 21.00 & Speech/communication impairment & 45 & 3 & 28.98 \\
\hline Learning disability/ADD/ADHD & 386 & 29 & 24.44 & Learning disability/ADD/ADHD & 603 & 45 & 26.31 \\
\hline Mobility impairment & 51 & 4 & 31.02 & Mobility impairment & 176 & 13 & 32.03 \\
\hline in the use of hands/arms & 47 & 3 & 29.49 & Limitation in the use of hands/arms & 172 & 13 & 32.64 \\
\hline Medically related/health problem & 67 & 5 & 30.82 & Medically related/health problem & 258 & 19 & 32.39 \\
\hline Psychological/psychiatric disability & 172 & 13 & 27.52 & Psychological/psychiatric disability & 429 & 32 & 29.25 \\
\hline Neurological impairment & 27 & 2 & 29.63 & Neurological impairment & 107 & 8 & 30.98 \\
\hline $\begin{array}{l}\text { Pervasive developmental } \\
\text { disorder (e.g., Asperger's) }\end{array}$ & 6 & $<1$ & 25.00 & $\begin{array}{l}\text { Pervasive developmental disorder } \\
\text { (e.g., Asperger's) }\end{array}$ & 17 & 1 & 25.59 \\
\hline Other & $\sigma$ & 0 & $\mathrm{n} / \mathrm{a}$ & Other & 4 & $<1$ & 38.50 \\
\hline Multiple & 460 & 34 & 30.70 & & & & \\
\hline Total number of students & 1,354 & & & Total disabilities reported by the 1,354 students & 2,062 & & \\
\hline
\end{tabular}

${ }^{\mathrm{a}} 1,354$ participants reported 2,062 disabilities. Subjects reporting a disability may have more than one impairment. 
Table 2. Participants enrolled in each discipline broken down by sex.

\begin{tabular}{|c|c|c|c|c|c|c|c|c|c|}
\hline \multirow[b]{2}{*}{ Disciplines } & \multicolumn{2}{|c|}{ Total sample } & \multicolumn{2}{|c|}{ Females } & \multicolumn{2}{|c|}{ Males } & \multirow[b]{2}{*}{$\chi^{2}$} & \multirow[b]{2}{*}{ df } & \multirow[b]{2}{*}{$p$} \\
\hline & $n$ & $\%$ & $n$ & $\%$ & $n$ & $\%$ & & & \\
\hline Social sciences & 385 & 29 & 269 & 31 & 116 & 26 & 3.68 & 1,385 & 0.055 \\
\hline Arts and humanities & 241 & 18 & 175 & 20 & 65 & 14 & 6.30 & 1,240 & 0.012 \\
\hline Science and engineering & 215 & 16 & 117 & 13 & 98 & 22 & 15.23 & 1,215 & 0.000 \\
\hline Professional programs & 171 & 13 & 136 & 15 & 34 & 8 & 17.10 & 1,170 & 0.000 \\
\hline Business & 146 & 11 & 77 & 9 & 68 & 15 & 11.99 & 1,145 & 0.001 \\
\hline Computer and information technology & 72 & 5 & 24 & 3 & 48 & 11 & 36.10 & 1,72 & 0.000 \\
\hline Career or technical program & 61 & 5 & 52 & 6 & 9 & 2 & 10.59 & 1,61 & 0.001 \\
\hline Upgrading and continuing education & 26 & 2 & 17 & 2 & 8 & 2 & 0.05 & 1,25 & 0.828 \\
\hline Other & 18 & 1 & 11 & 1 & 7 & 2 & 0.19 & 1,18 & 0.662 \\
\hline Total & 1,335 & 100 & 878 & 100 & 453 & 100 & & & \\
\hline
\end{tabular}

Note: $N=1,335 ; 16$ female and 3 male participants did not report what discipline they are studying, and 1 participant studying business, 1 participant studying arts and humanities, 1 participant in upgrading/continuing education, and 1 participant studying a professional program did not report sex. 


\section{C.S. Fichten et al.}

\section{Specialised softwarelhardware used}

We asked participants to check as many of the hardware/software items as they used from the listing in Table 3.

\section{Overall Criterion Items}

Using a 6-point Likert scale ( $1=$ strongly disagree, $6=$ strongly agree), participants rated two items that inquired about how well their ICT and/or adaptive computer needs were being met on campus and at home.

\section{POSITIVES Scale (Post-secondary Information Technology Initiative Scale)}

This 26-item objective measure concerning how well students' ICT-related needs are being met uses 6 -point Likert scaling ( $1=$ strongly disagree, $6=$ strongly agree) where students indicate their level of agreement with each of 26 positively worded items (Fichten et al. 2010). The measure has three factor analysis derived Subscales [ICTs at School (i.e. on campus) Meet Student's Needs, ICTs at Home Meet Student's Needs, E-learning ICTs Meet Student's Needs] and a Total score. Four-week test retest reliabilities for the three Subscales ranged from 0.73 to 0.79 , and the reliability of the Total score was 0.81 . Cronbach's alpha, a measure of internal consistency, ranged from 0.79 to 0.91 for the Subscales. It was 0.94 for the Total score. Split-half reliabilities and Subscale: Total correlations all exceeded 0.70. Construct, concurrent and criterion validity data indicated good psychometric properties for the Total score as well as the Subscales. English and French versions as well as alternate formats that could be completed online, on paper (printable PDF) and within a Microsoft Word document were found to be equivalent.

\section{Procedure}

A total of 1,354 Canadian university and junior/community college students with various disabilities completed the web-based questionnaire battery. Participants were recruited through (1) email discussion lists dealing with Canadian post-secondary education and disability; (2) project partners; and (3) contacting participants of our previous investigations. The research protocol was approved by Dawson College's Human Research Ethics Committee.

Potential participants were asked to email us for more information. Those indicating interest were directed to the study's website where they chose the language (English or French) to read the consent form, which provided information about the study, including the $\$ 10$ honorarium. Clicking the "I consent" button brought participants to the online questionnaire, which took approximately 10 minutes to complete.

\section{Results}

\section{Sample characteristics}

Table 1 indicates that approximately $2 / 3$ of the sample consisted of women. There was no significant difference between males and females with regard to age. The 1,354 students reported a total of 2,062 disabilities (mean $=1.52$ 
Table 3. Adaptive computer technologies used by participants.

\begin{tabular}{|c|c|c|c|c|c|c|c|c|c|c|c|c|c|c|c|c|c|c|c|c|c|}
\hline \multirow[b]{2}{*}{ Type of disability/impairment } & \multirow[b]{2}{*}{$\begin{array}{c}\text { Total } \\
n\end{array}$} & \multicolumn{2}{|c|}{$\begin{array}{c}\text { Software } \\
\text { that improves } \\
\text { writing } \\
\text { quality }\end{array}$} & \multicolumn{2}{|c|}{$\begin{array}{l}\text { Software that } \\
\text { reads what is } \\
\text { on the screen }\end{array}$} & \multicolumn{2}{|c|}{$\begin{array}{l}\text { Scanning } \\
\text { and optical } \\
\text { character } \\
\text { recognition } \\
\text { (OCR) }\end{array}$} & \multicolumn{2}{|c|}{$\begin{array}{l}\text { Dictation } \\
\text { software }\end{array}$} & \multicolumn{2}{|c|}{$\begin{array}{l}\text { Software that } \\
\text { enlarges what } \\
\text { is on the } \\
\text { screen }\end{array}$} & \multicolumn{2}{|c|}{$\begin{array}{l}\text { Large screen } \\
\text { monitor }\end{array}$} & \multicolumn{2}{|c|}{$\begin{array}{l}\text { Alternative } \\
\text { mouse }\end{array}$} & \multicolumn{2}{|c|}{$\begin{array}{l}\text { Adapted } \\
\text { keyboard }\end{array}$} & \multicolumn{2}{|c|}{$\begin{array}{c}\text { Refreshable } \\
\text { Braille } \\
\text { display } \\
\end{array}$} & \multicolumn{2}{|r|}{ Other } \\
\hline & & $n$ & $\begin{array}{c}\% \text { of } \\
\text { Students }\end{array}$ & $n$ & $\begin{array}{c}\% \text { of } \\
\text { Students }\end{array}$ & $n$ & $\begin{array}{c}\% \text { of } \\
\text { Students }\end{array}$ & $n$ & $\begin{array}{c}\% \text { of } \\
\text { Students }\end{array}$ & $n$ & $\begin{array}{c}\% \text { of } \\
\text { Students }\end{array}$ & $n$ & $\begin{array}{c}\% \text { of } \\
\text { Students }\end{array}$ & $n$ & $\begin{array}{c}\% \text { of } \\
\text { Students }\end{array}$ & $n$ & $\begin{array}{c}\% \text { of } \\
\text { Students }\end{array}$ & $n$ & $\begin{array}{c}\% \text { of } \\
\text { Students }\end{array}$ & $n$ & $\begin{array}{c}\% \text { of } \\
\text { Students } \\
\end{array}$ \\
\hline Totally blind & 17 & 7 & 41 & 17 & 100 & 15 & 88 & 0 & 0 & 0 & 0 & 0 & 0 & 1 & 6 & 0 & 0 & 12 & 71 & 3 & 18 \\
\hline Low vision & 62 & 27 & 44 & 29 & 47 & 18 & 29 & 2 & 3 & 44 & 71 & 31 & 50 & 4 & 6 & 4 & 6 & 3 & 5 & 0 & 0 \\
\hline Deaf & 14 & 7 & 50 & 1 & 7 & 4 & 29 & 0 & 0 & 0 & 0 & 0 & 0 & 2 & 14 & 0 & 0 & 0 & 0 & 2 & 14 \\
\hline Hard of hearing & 43 & 23 & 53 & 4 & 9 & 2 & 5 & 2 & 5 & 2 & 5 & 2 & 5 & 4 & 9 & 0 & 0 & 0 & 0 & 3 & 7 \\
\hline $\begin{array}{l}\text { Speech/communication } \\
\text { impairment }\end{array}$ & 2 & 2 & 100 & 0 & 0 & 0 & 0 & 0 & 0 & 0 & 0 & 0 & 0 & 0 & 0 & 0 & 0 & 0 & 0 & 0 & 0 \\
\hline $\begin{array}{l}\text { Learning disability/ADD/ } \\
\text { ADHD }\end{array}$ & 386 & 299 & 77 & 129 & 33 & 80 & 21 & 77 & 20 & 28 & 7 & 16 & 4 & 12 & 3 & 5 & 1 & 0 & 0 & 17 & 4 \\
\hline Mobility impairment & 51 & 23 & 45 & 2 & 4 & 2 & 4 & 7 & 14 & 3 & 6 & 2 & 4 & 3 & 6 & 0 & 0 & 0 & 0 & 2 & 4 \\
\hline $\begin{array}{l}\text { Limitation in the use of } \\
\text { hands/arms }\end{array}$ & 47 & 27 & 57 & 2 & 4 & 2 & 4 & 14 & 30 & 2 & 4 & 5 & 11 & 10 & 21 & 9 & 19 & 0 & 0 & 2 & 4 \\
\hline $\begin{array}{l}\text { Medically related/health } \\
\text { problem }\end{array}$ & 67 & 36 & 54 & 2 & 3 & 3 & 4 & 4 & 6 & 11 & 16 & 5 & 7 & 3 & 4 & 0 & 0 & 0 & 0 & 3 & 4 \\
\hline $\begin{array}{l}\text { Psychological/psychiatric } \\
\text { disability }\end{array}$ & 172 & 97 & 56 & 12 & 7 & 11 & 6 & 8 & 5 & 13 & 8 & 8 & 5 & 10 & 6 & 1 & 1 & 0 & 0 & 2 & 1 \\
\hline Neurological impairment & 27 & 14 & 52 & 4 & 15 & 2 & 7 & 5 & 19 & 0 & 0 & 1 & 4 & 1 & 4 & 0 & 0 & 0 & 0 & 1 & 4 \\
\hline PDD & 6 & 5 & 83 & 0 & 0 & 0 & 0 & 0 & 0 & 0 & 0 & 0 & 0 & 0 & 0 & 0 & 0 & 0 & 0 & 0 & 0 \\
\hline $\begin{array}{l}\text { Multiple disabilities/ } \\
\text { impairments }\end{array}$ & 460 & 313 & 68 & 107 & 23 & 86 & 19 & 99 & 22 & 95 & 21 & 73 & 16 & 54 & 12 & 26 & 6 & 8 & 2 & 23 & 5 \\
\hline Total & 1,354 & 880 & 65 & 309 & 23 & 225 & 17 & 218 & 16 & 198 & 15 & 143 & 11 & 104 & 8 & 45 & 3 & 23 & 2 & 58 & 4 \\
\hline
\end{tabular}




\section{C.S. Fichten et al.}

disabilities/student); 460 students reported more than one disability: $22 \%$ indicated two, $8 \%$ indicated three, and $4 \%$ indicated four or more disabilities. Table 1 shows that the most common disability reported by participants was a learning disability (with or without attention deficit or attention deficit hyperactivity disorder), followed by a psychological/psychiatric disability and a medically related/health problem.

\section{Students' disciplines}

Findings in Table 2 show that the largest proportion of participants were enrolled in social sciences, followed by arts and humanities and by science and engineering. Chi square tests indicate that males were more likely than females to be enrolled in business, science and engineering, and computer and information technology programmes, while females were more likely to be enrolled in arts and humanities, professional programmes (e.g. law, social work), and career or technical programmes (e.g. nursing, radiation oncology).

To examine whether the ICT-related needs of students enrolled in different programmes are differentially met, we carried out a multivariate analysis of variance (MANOVA) on the two Overall Criterion Items as well as on the POSITIVES Scale Subscale and Total scores. The MANOVA was not significant.

To evaluate the representativeness of the sample, we recoded disciplines in accordance with Holmes (2005), who examined the disciplines of 10,606 university undergraduates without disabilities and 691 with disabilities based on random sampling. Results in Table 4 show that in both our sample and in that of Holmes, the most popular disciplines for students with disabilities, in rank order, were social sciences, arts and humanities, and science and engineering. The percentages, both in our sample as well as in Holmes' sample, show that students with disabilities were more likely than non-disabled students to be enrolled in a social science or in arts and humanities programmes and less likely to be taking business. In Holmes' sample, students with disabilities were less likely to be taking science and engineering than non-disabled students. This was not the case, however, in our sample.

Table 4. Disciplines: comparison of university students in the present sample with those in Holmes (2005).

\begin{tabular}{lccccc}
\hline & \multicolumn{2}{c}{ Present sample } & & \multicolumn{2}{c}{ Holmes' sample } \\
\cline { 2 - 3 } \cline { 5 - 6 } Disciplines & \multicolumn{2}{c}{$\begin{array}{c}\text { Students with } \\
\text { disabilities (\%) }\end{array}$} & & $\begin{array}{c}\text { Students with } \\
\text { disabilities (\%) }\end{array}$ & $\begin{array}{c}\text { Students without } \\
\text { disabilities (\%) }\end{array}$ \\
\hline Social sciences & 306 & 32 & & 21 & 19 \\
Arts and humanities & 206 & 21 & & 26 & 18 \\
Science and engineering & 205 & 21 & & 15 & 82 \\
Professional programs & 137 & 14 & & 8 & 16 \\
Business & 84 & 9 & & 10 & 16 \\
Other & 21 & 2 & & 20 & 100 \\
Total & 959 & 100 & & 100 & \\
\hline
\end{tabular}

Note: $N=959$ for our study; 13 university participants did not indicate their discipline. Numbers do not sum to $100 \%$ because of rounding errors. 


\section{Specialised softwarelhardware used}

Of the 1,354 students, 317 indicated that they did not use any of the specialised software and/or hardware items on our list. Table 3 shows the types of specialised ICTs the remaining students with different disabilities reported using. Overall, the findings indicate that specialised software which improves writing quality, such as grammar and spell checkers, were used by over $40 \%$ of students in the sample. This was followed, in rank order of popularity, by software that reads what is on the screen, scanning and optical character recognition (OCR), dictation software, and software that enlarges information on the screen.

However, the number of students with different disabilities varies in the sample, and the very large number of students with learning disabilities, psychological/ psychiatric impairments, and multiple disabilities can skew the results. Therefore, in Table 3 we present the specialised ICTs indicated by students in each disability grouping.

\section{How well students' ICT-related needs are being met in different contexts}

Table 5 shows mean scores for the POSITIVES Scale. To examine how well students' ICT-related needs are being met, we compared scores on the three Subscales using a one-way repeated measures ANOVA. Results indicate that scores on the three Subscales differ significantly, $F(22,086)=162.05, p<0.001$. Post hoc tests show that the three Subscale scores are all significantly different from each other. Subscale 2 (ICTs at Home Meet Student's Needs) has the lowest, and Subscale 3 (E-learning ICTs Meet Student's Needs) has the highest means.

Scores in Table 5 also indicate that although all items have means that are more favourable than unfavourable (i.e. $>3.5$ on the 6-point scale), the most problematic items are those that deal with the availability of computers with adaptive software/ hardware on campus in specialised computer laboratories as well as those available through the institution's loan programme. In addition, funding for computer technologies for personal use as well as problems with training, both on and off campus, had relatively low scores, as did the item dealing with poor technical support when the student is not on campus.

On the other hand, the results also show that students felt that: the institution's web pages are accessible; they can effectively use the computer technologies they need; expertise in adaptive ICTs was readily available on campus; needed electronic format course material was available; and the institution's interactive online services (e.g. registering, financial aid applications on the Internet) as well as the library's computer systems were generally quite accessible.

\section{Students with different disabilities}

The findings above represent the sample as a whole. To examine how well the specific needs of students with different disabilities are being met, in Table 6 we provide POSITIVES Scale scores for participants with different disabilities. We also conducted a series of one-way ANOVAs on scores for 10 of the 12 groups [sample sizes for the speech/communication impairment group and the pervasive developmental disorder (PDD) group were too small]. The ANOVAs show significant differences among groups for 20 of the 26 POSITIVES Scale single items, all three 


\section{C.S. Fichten et al.}

Table 5. POSITIVES Scale instructions, scoring, subscales, and items in rank order within subscales.

Subscale, item number, item wording

\begin{tabular}{cc} 
Mean & SD \\
\hline 4.65 & 1.03 \\
5.00 & 1.37
\end{tabular}

Subscale 1 - ICTs at School Meet Student's Needs

10 There is at least one person on staff at my school who has expertise in adaptive hardware and software (e.g., knowledgeable about software that reads what is on the screen, keeps up-to-date with the latest in adapted keyboards)

2 The hours of access to computer technologies at my school meet my needs

24 The physical access to computer technologies at my school meets my needs (e.g., adjustable table, wide enough doorway)

3 At my school, computer technologies are sufficiently up-to-date to meet my needs (e.g., grammar checking, adaptive mouse, software that reads what is on the screen)

1 My school has enough computers with Internet access to meet my needs

9 When I approach staff at my institution with problems related to the accessibility of computer technologies on campus they act quickly to resolve any issues (e.g., cannot see the PowerPoint presentation, cannot hear a video clip, need a grammar checker to write an essay)

8 The technical support provided at my school for computer technologies meets my needs

14 Informal help is available at my school to show me how to use computer technologies if I need this

5 The availability of computer technologies in my school's general use computer labs meet my needs

13 Training provided by my school on how to use the computer technologies meets my needs

11 The availability of technical support when I am not at school meets my needs (e.g., school IT help desk, vendor support)

4 There are enough computer technologies in my school's specialised labs/centres for students with disabilities to meet my needs

Subscale 2 - ICTs at Home Meet Student's Needs

12 I know how to effectively use the computer technologies that I need

23 My personal computer technologies are sufficiently up-to-date to meet my needs

7 Funding for computer technologies for personal use is adequate to meet my needs (e.g., government, foundation, rehab centre, loan program)

6 My school's loan program for computer technologies meets my needs

15 Training available off campus on how to use computer technologies meets my needs

Subscale 3 - E-learning ICTs Meet Student's Needs

25 My school's web pages are accessible to me

26 The availability of electronic format course materials meets my needs (e.g., Word, PDF, MP3)

22 The accessibility of the library's computer systems meets my needs (e.g., catalogues, databases, CD-ROMs)

16 When professors use e-learning, it is accessible to me (e.g., Power- 
Table 5 (Continued)

\begin{tabular}{llc}
\hline Subscale, item number, item wording & Mean & SD \\
\hline $18 \quad \begin{array}{l}\text { Distance education courses offered by my institution are accessible } \\
\text { to me }\end{array}$ & 4.70 & 1.56 \\
$20 \quad \begin{array}{l}\text { I feel comfortable using needed computer technologies in the } \\
\text { classroom }\end{array}$ & 4.63 & 1.54 \\
$19 \quad \begin{array}{l}\text { If I bring computer technology into the classroom I am able to use it } \\
\text { (e.g., can plug it in) }\end{array}$ & 4.59 & 1.50 \\
Total (average) score & 4.75 & 0.86 \\
\hline
\end{tabular}

Instructions and scoring. "For all statements, rate your level of agreement using the following scale: $1=$ Strongly Disagree, 2 =Moderately Disagree, $3=$ Slightly Disagree, $4=$ Slightly Agree, $5=$ Moderately Agree, $6=$ Strongly Agree. You may also indicate "not applicable." Scoring: average all single item scores, other than "not applicable," for each of the three Subscales. For the Total score, average all single item scores other than "not applicable."

Note: $N=1354$.

Subscales as well as the Total score. The results indicate that the needs of students who are totally blind, those with multiple disabilities, and those with low vision were met least well. Needs of students who are hard of hearing, those who have a medically related/health problem or a mobility impairment and those with psychological/psychiatric disabilities were met best.

Subscale results, however, suggest that while this pattern is true for Subscales 1 and 3, the pattern of results is very different for Subscale 2 (i.e. home use). Here, the findings indicate that the ICT-related needs of the following groups were met least well: multiple disabilities, psychological/psychiatric disability and learning disability/ ADD/ADHD. In contrast, the needs of students with mobility impairments, those who are hard of hearing, and those who are totally blind were met best in this context.

\section{On and off campus}

Table 7 provides comparative information, using POSITIVES Scale single items, about the views of students with different disabilities about how well their ICTrelated needs are being met in various contexts at home and at school (i.e. on campus). Two-way between - within ANOVA results $[10$ groups $\times 2$ location (home, school)] on three dependent variables (ICTs sufficiently up-to-date, technical support needs met, training needs met) indicate significant differences among groups on all variables.

Significant location main effects on technical support and on training indicate that students' technical support as well as training needs were significantly better met on campus than at home. In addition, we found a significant interaction effect on the ICTs up-to-date item. Post hoc tests show that students who were totally blind indicated that their technologies were significantly more up-to-date at home, while students with learning disabilities, as well as with medically related, psychologically related and multiple disabilities indicated the opposite.

\section{Colleges versus universities}

A MANOVA on the two Overall Criterion Items and on POSITIVES Scale Subscale and Total scores was significant, $F(6,978)=2.41, p=0.026$. Test results in Table 8 indicate that junior/community college students' ICT-related needs were better met 
Table 6. Mean POSITIVES Scale scores for participants with different disabilities and one-way ANOVA test results.

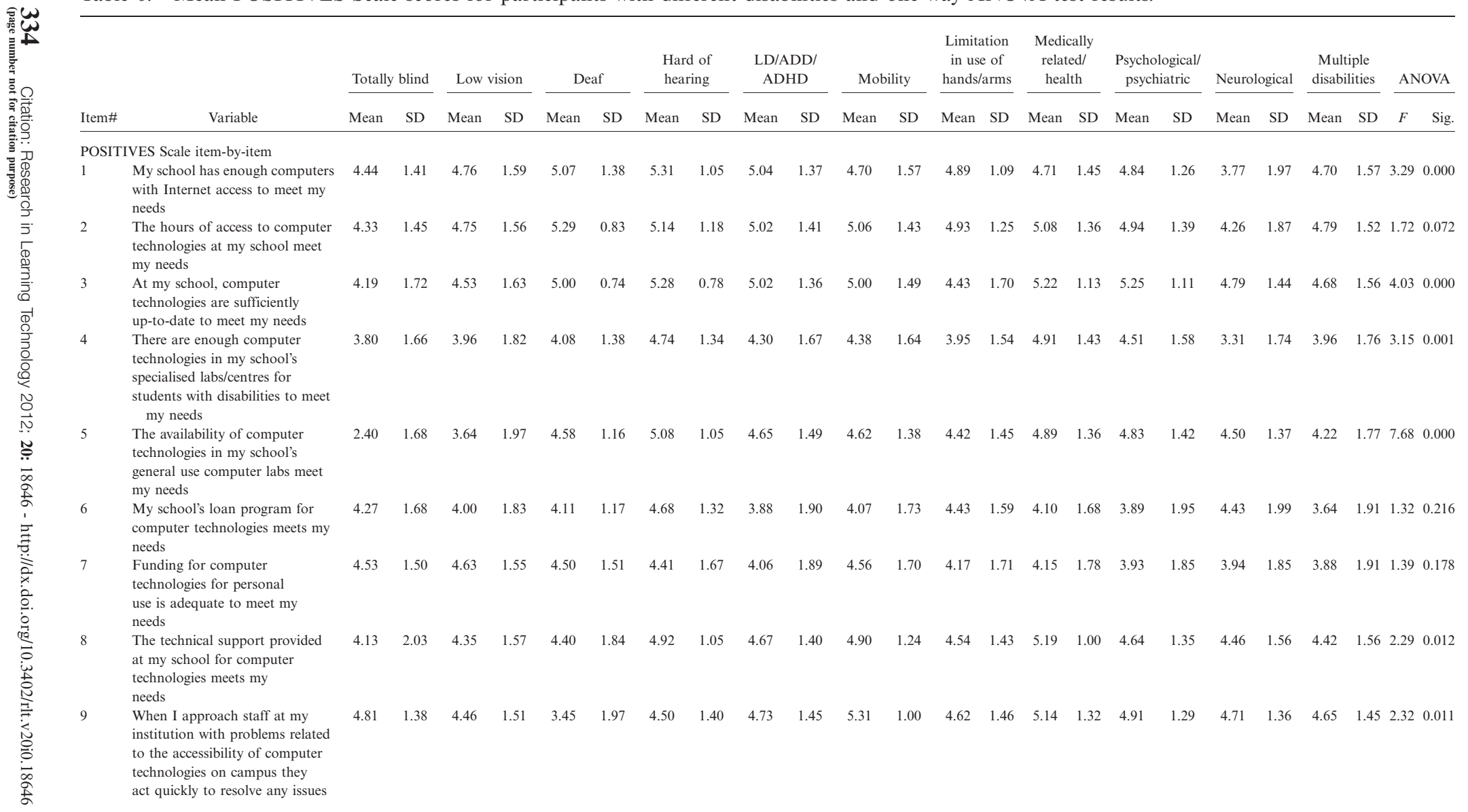




\begin{tabular}{|c|c|c|c|c|c|c|c|c|c|c|c|c|c|c|c|c|c|c|c|c|c|c|c|c|c|}
\hline \multirow[b]{2}{*}{ Item\# } & \multirow[b]{2}{*}{ Variable } & \multicolumn{2}{|c|}{ Totally blind } & \multicolumn{2}{|c|}{ Low vision } & \multicolumn{2}{|c|}{ Deaf } & \multicolumn{2}{|c|}{$\begin{array}{l}\text { Hard of } \\
\text { hearing }\end{array}$} & \multicolumn{2}{|c|}{$\begin{array}{l}\text { LD/ADD/ } \\
\text { ADHD }\end{array}$} & \multicolumn{2}{|c|}{ Mobility } & \multicolumn{2}{|c|}{$\begin{array}{r}\text { Limitation } \\
\text { in use of } \\
\text { hands/arms } \\
\end{array}$} & \multicolumn{2}{|c|}{$\begin{array}{l}\text { Medically } \\
\text { related/ } \\
\text { health } \\
\end{array}$} & \multicolumn{2}{|c|}{$\begin{array}{l}\text { Psychological/ } \\
\text { psychiatric }\end{array}$} & \multicolumn{2}{|c|}{ Neurological } & \multicolumn{2}{|c|}{$\begin{array}{c}\text { Multiple } \\
\text { disabilities } \\
\end{array}$} & \multicolumn{2}{|c|}{ ANOVA } \\
\hline & & Mean & $\mathrm{SD}$ & Mean & $\mathrm{SD}$ & Mean & $\mathrm{SD}$ & Mean & $\mathrm{SD}$ & Mean & SD & Mean & $\mathrm{SD}$ & Mean & $\mathrm{SD}$ & Mean & $\mathrm{SD}$ & Mean & SD & Mean & SD & Mean & $\mathrm{SD}$ & $F$ & Sig. \\
\hline 10 & $\begin{array}{l}\text { There is at least one person on } \\
\text { staff at my school who has } \\
\text { expertise in adaptive hardware } \\
\text { and software }\end{array}$ & 4.76 & 1.71 & 4.93 & 1.47 & 3.91 & 1.58 & 4.76 & 1.52 & 5.22 & 1.23 & 4.89 & 1.53 & 4.92 & 1.52 & 5.13 & 1.14 & 5.10 & 1.19 & 5.35 & 0.86 & 4.83 & 1.47 & 2.55 & 0.005 \\
\hline 11 & $\begin{array}{l}\text { The availability of technical } \\
\text { support when I am not at school } \\
\text { meets my needs }\end{array}$ & 3.88 & 2.06 & 4.41 & 1.55 & 3.80 & 1.32 & 4.63 & 1.21 & 4.29 & 1.51 & 4.68 & 1.33 & 4.40 & 1.31 & 4.62 & 1.47 & 4.15 & 1.48 & 4.31 & 1.30 & 4.01 & 1.65 & 1.81 & 0.055 \\
\hline 12 & $\begin{array}{l}\text { I know how to effectively use } \\
\text { the computer technologies that } \\
\text { I need }\end{array}$ & 5.47 & 0.72 & 5.32 & 1.13 & 5.79 & 0.43 & 5.17 & 0.93 & 5.07 & 1.25 & 5.30 & 1.18 & 5.27 & 0.91 & 5.18 & 1.10 & 5.07 & 1.25 & 5.32 & 0.95 & 4.92 & 1.36 & 2.00 & 0.030 \\
\hline 13 & $\begin{array}{l}\text { Training provided by my school } \\
\text { on how to use the computer } \\
\text { technologies meets my needs }\end{array}$ & 3.93 & 2.12 & 4.23 & 1.39 & 5.13 & 1.13 & 4.42 & 1.54 & 4.37 & 1.55 & 4.83 & 1.62 & 4.35 & 1.59 & 4.70 & 1.37 & 4.44 & 1.46 & 4.50 & 1.54 & 4.00 & 1.70 & 2.33 & 0.010 \\
\hline 14 & $\begin{array}{l}\text { Informal help is available at my } \\
\text { school to show me how to use } \\
\text { technologies if I need this }\end{array}$ & 4.24 & 1.75 & 4.36 & 1.52 & 4.80 & 1.62 & 4.35 & 1.44 & 4.66 & 1.45 & 4.93 & 1.23 & 4.68 & 1.29 & 4.78 & 1.30 & 4.58 & 1.34 & 4.35 & 1.47 & 4.37 & 1.54 & 1.57 & 0.110 \\
\hline 15 & $\begin{array}{l}\text { Training available off campus on } \\
\text { how to use computer technologies } \\
\text { meets my needs }\end{array}$ & 3.79 & 2.12 & 3.75 & 1.82 & 3.83 & 1.94 & 4.20 & 1.35 & 3.70 & 1.63 & 3.88 & 1.51 & 3.48 & 1.62 & 3.94 & 1.56 & 3.65 & 1.60 & 3.83 & 1.95 & 3.43 & 1.68 & 0.99 & 0.453 \\
\hline 16 & $\begin{array}{l}\text { When professors use e-learning, it } \\
\text { is accessible to me }\end{array}$ & 4.19 & 1.28 & 4.80 & 1.34 & 4.54 & 1.90 & 5.08 & 1.14 & 5.02 & 1.25 & 5.48 & 0.95 & 5.20 & 1.21 & 5.27 & 1.24 & 5.33 & 1.00 & 4.95 & 1.43 & 4.77 & 1.47 & 4.06 & 0.000 \\
\hline 17 & $\begin{array}{l}\text { I have no problem when } \\
\text { professors use e-learning for tests } \\
\text { and exams }\end{array}$ & 3.31 & 1.75 & 4.33 & 1.76 & 5.25 & 1.16 & 5.03 & 1.42 & 4.75 & 1.54 & 5.15 & 1.31 & 4.63 & 1.79 & 5.24 & 1.35 & 4.95 & 1.41 & 5.07 & 0.88 & 4.52 & 1.65 & 3.21 & 0.000 \\
\hline 18 & $\begin{array}{l}\text { Distance education courses } \\
\text { offered by my institution are } \\
\text { accessible to }\end{array}$ & 3.91 & 1.64 & 4.96 & 1.10 & 5.75 & 0.50 & 5.36 & 1.11 & 4.78 & 1.53 & 5.15 & 1.51 & 4.85 & 1.49 & 5.03 & 1.47 & 4.86 & 1.50 & 4.90 & 0.99 & 4.40 & 1.68 & 2.63 & 0.004 \\
\hline 19 & $\begin{array}{l}\text { If I bring computer technology } \\
\text { into the classroom I am able to } \\
\text { use it }\end{array}$ & 5.63 & 0.62 & 4.91 & 1.30 & 4.80 & 1.69 & 4.79 & 1.34 & 4.58 & 1.44 & 4.95 & 1.34 & 3.97 & 1.48 & 4.83 & 1.35 & 4.50 & 1.55 & 3.96 & 1.99 & 4.53 & 1.56 & 2.69 & 0.003 \\
\hline 20 & $\begin{array}{l}\text { I feel comfortable using needed } \\
\text { computer technologies in the }\end{array}$ & 5.65 & 0.61 & 4.67 & 1.57 & 4.36 & 1.91 & 4.82 & 1.39 & 4.58 & 1.55 & 5.16 & 1.27 & 4.55 & 1.58 & 5.16 & 1.30 & 4.73 & 1.47 & 4.36 & 1.53 & 4.47 & 1.61 & 2.53 & 0.005 \\
\hline 21 & $\begin{array}{l}\text { My school's interactive online } \\
\text { services are accessible to me }\end{array}$ & 4.35 & 1.80 & 5.32 & 1.05 & 5.21 & 1.19 & 5.79 & 0.56 & 5.38 & 1.00 & 5.67 & 0.75 & 5.43 & 0.89 & 5.44 & 1.13 & 5.41 & 0.98 & 5.19 & 1.10 & 5.29 & 1.15 & 3.10 & 0.001 \\
\hline 22 & $\begin{array}{l}\text { The accessibility of the library's } \\
\text { computer systems meets my } \\
\text { needs }\end{array}$ & 3.86 & 1.88 & 4.62 & 1.52 & 5.58 & 0.51 & 5.56 & 0.59 & 5.11 & 1.19 & 5.21 & 1.32 & 5.19 & 1.06 & 5.38 & 1.05 & 5.07 & 1.32 & 4.77 & 1.48 & 4.87 & 1.35 & 4.40 & 0.000 \\
\hline
\end{tabular}




\begin{tabular}{|c|c|c|c|c|c|c|c|c|c|c|c|c|c|c|c|c|c|c|c|c|c|c|c|c|c|}
\hline \multirow[b]{2}{*}{ Item\# } & \multirow[b]{2}{*}{ Variable } & \multicolumn{2}{|c|}{ Totally blind } & \multicolumn{2}{|c|}{ Low vision } & \multicolumn{2}{|c|}{ Deaf } & \multicolumn{2}{|c|}{$\begin{array}{l}\text { Hard of } \\
\text { hearing }\end{array}$} & \multicolumn{2}{|c|}{$\begin{array}{l}\text { LD/ADD/ } \\
\text { ADHD }\end{array}$} & \multicolumn{2}{|c|}{ Mobility } & \multicolumn{2}{|c|}{$\begin{array}{c}\text { Limitation } \\
\text { in use of } \\
\text { hands/arms }\end{array}$} & \multicolumn{2}{|c|}{$\begin{array}{c}\text { Medically } \\
\text { related/ } \\
\text { health }\end{array}$} & \multicolumn{2}{|c|}{$\begin{array}{c}\text { Psychological/ } \\
\text { psychiatric }\end{array}$} & \multicolumn{2}{|c|}{ Neurological } & \multicolumn{2}{|c|}{$\begin{array}{c}\text { Multiple } \\
\text { disabilities }\end{array}$} & \multicolumn{2}{|c|}{ ANOVA } \\
\hline & & Mean & SD & Mean & SD & Mean & SD & Mean & SD & Mean & SD & Mean & SD & Mean & SD & Mean & SD & Mean & $\mathrm{SD}$ & Mean & SD & Mean & SD & $F$ & Sig. \\
\hline & My personal computer & 5.35 & 1.06 & 4.95 & 1.21 & 5.25 & 0.87 & 5.07 & 1.27 & 4.84 & 1.51 & 5.22 & 1.28 & 4.91 & 1.44 & 4.69 & 1.67 & 4.85 & 1.46 & 4.78 & 1.50 & 4.51 & 1.62 & 2.63 & 0.004 \\
\hline
\end{tabular}

technologies are sufficiently

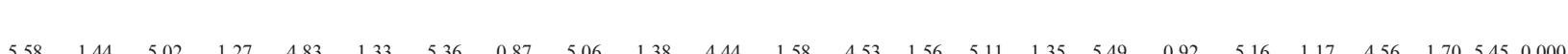

up-to-date to meet my needs

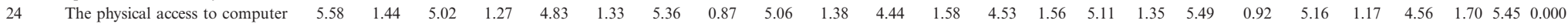
technologies at my school mets

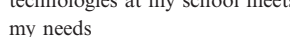

25 My school's web pages are

accessible to me

format course materials meets my

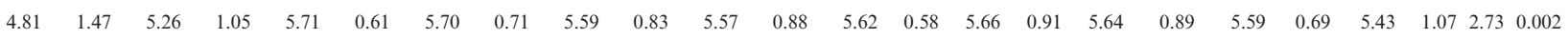
needs

POSITIVES Scale Subscales

$\begin{array}{lllllllllllllllllllllllll}\text { Subscale 1 - ICTs at School Meet } & 4.21 & 1.12 & 4.47 & 1.13 & 4.60 & 0.81 & 4.95 & 0.76 & 4.76 & 0.98 & 4.81 & 0.97 & 4.56 & 0.86 & 4.94 & 0.86 & 4.81 & 0.89 & 4.52 & 1.08 & 4.45 & 1.11 & 4.08 & 0.000\end{array}$

Student's Needs

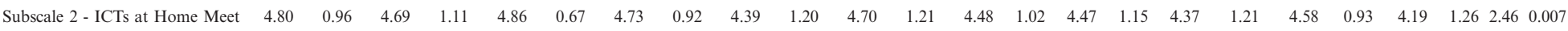

Student's Needs

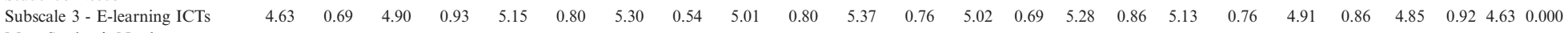

Meet Student's Needs

Total (average) score

$\begin{array}{llllllllllllllllllllllll}4.48 & 0.73 & 4.67 & 0.90 & 4.86 & 0.64 & 5.05 & 0.63 & 4.81 & 0.84 & 5.03 & 0.82 & 4.72 & 0.73 & 5.03 & 0.78 & 4.87 & 0.79 & 4.69 & 0.90 & 4.57 & 0.92 & 4.71 & 0.000\end{array}$

Note: Scores of participants with speech/communication-related disabilities and PDD are not presented because of small sample sizes. Range of sample sizes is as follows: totally blind 11-17, low vision 32-62, deaf 4-14, hard of hearing 22-43, LD/ADD/ADHD 266-386, mobility impairment 26-51, limitation in the use of arms or hands 23-47, medically related/health problem 29-67, psychological/psychiatric 66-172, neurological 10-27, multiple disabilities $274-460$. Degrees of freedom for the ANOVAs range from $(10,924)$ to $(10,1335)$. 
Table 7. How well students' needs are met at home and at school in three contexts: comparison of scores of students with different disabilities.

\begin{tabular}{|c|c|c|c|c|c|c|c|c|c|c|c|c|c|c|c|c|c|}
\hline Item \# & Variable & & $\begin{array}{l}\text { Totally } \\
\text { blind }\end{array}$ & $\begin{array}{c}\text { Low } \\
\text { vision }\end{array}$ & Deaf & $\begin{array}{l}\text { Hard of } \\
\text { hearing }\end{array}$ & $\begin{array}{c}\text { Learning } \\
\text { disability/ } \\
\text { ADD/ } \\
\text { ADHD }\end{array}$ & $\begin{array}{c}\text { Mobility } \\
\text { impairment }\end{array}$ & $\begin{array}{l}\text { Limitation } \\
\text { in the use of } \\
\text { hands/arms }\end{array}$ & $\begin{array}{l}\text { Medically } \\
\text { related/health } \\
\text { problem }\end{array}$ & $\begin{array}{l}\text { Psychological/ } \\
\text { psychiatric } \\
\text { disability }\end{array}$ & $\begin{array}{l}\text { Neurological } \\
\text { impairment }\end{array}$ & $\begin{array}{c}\text { Multiple } \\
\text { disabilities }\end{array}$ & ANOVA & $F$ & df & Sig. \\
\hline \multicolumn{18}{|c|}{ ICTs up-to-date ${ }^{a}$} \\
\hline \multirow[t]{2}{*}{3} & At my school, computer & Mean & 4.19 & 4.53 & 5.10 & 5.26 & 5.01 & 5.07 & 4.43 & 5.22 & 5.28 & 4.79 & 4.69 & Location & 0.43 & 1,1172 & 0.490 \\
\hline & $\begin{array}{l}\text { technologies are } \\
\text { sufficiently up-to-date } \\
\text { to meet my needs }\end{array}$ & SD & 1.72 & 1.63 & 0.74 & 0.78 & 1.37 & 1.45 & 1.71 & 1.13 & 1.08 & 1.44 & 1.57 & Groups & 3.36 & 10,1172 & 0.001 \\
\hline \multirow[t]{2}{*}{23} & My personal computer & Mean & 5.38 & 4.89 & 5.30 & 5.09 & 4.81 & 5.19 & 5.00 & 4.63 & 4.81 & 4.71 & 4.48 & Interaction & 2.91 & 10,1172 & 0.001 \\
\hline & $\begin{array}{l}\text { technologies are } \\
\text { sufficiently up-to-date to } \\
\text { meet my needs }\end{array}$ & SD & 1.09 & 1.23 & 0.95 & 1.15 & 1.53 & 1.35 & 1.34 & 1.77 & 1.49 & 1.55 & 1.62 & & & & \\
\hline \multicolumn{18}{|c|}{ Technical support ${ }^{\mathrm{b}}$} \\
\hline \multirow[t]{2}{*}{8} & The technical support & Mean & 4.13 & 4.14 & 3.83 & 4.68 & 4.63 & 5.00 & 4.45 & 5.17 & 4.66 & 4.67 & 4.39 & Location & 11.65 & 1,923 & 0.001 \\
\hline & $\begin{array}{l}\text { provided at my school for } \\
\text { computer technologies } \\
\text { meets my needs }\end{array}$ & SD & 2.03 & 1.60 & 2.23 & 1.21 & 1.44 & 1.00 & 1.48 & 1.02 & 1.37 & 1.45 & 1.59 & Groups & 2.10 & 10,923 & 0.022 \\
\hline \multirow[t]{2}{*}{11} & The availability of & Mean & 3.75 & 4.28 & 3.33 & 4.55 & 4.24 & 4.76 & 4.33 & 4.56 & 4.09 & 4.27 & 4.01 & Interaction & 0.95 & 10,923 & 0.483 \\
\hline & $\begin{array}{l}\text { technical support when I } \\
\text { am not at school meets my } \\
\text { needs }\end{array}$ & SD & 2.05 & 1.59 & 1.51 & 1.26 & 1.52 & 1.33 & 1.31 & 1.50 & 1.52 & 1.33 & 1.63 & & & & \\
\hline \multicolumn{18}{|c|}{ Training $^{\mathrm{b}}$} \\
\hline \multirow[t]{2}{*}{13} & Training provided by my & Mean & 3.79 & 4.25 & 4.50 & 4.50 & 4.23 & 4.43 & 4.10 & 4.89 & 4.25 & 4.80 & 3.77 & Location & 28.53 & 1,688 & 0.000 \\
\hline & $\begin{array}{l}\text { school on how to use the } \\
\text { computer technologies } \\
\text { meets my }\end{array}$ & SD & 2.12 & 1.44 & 1.29 & 1.44 & 1.59 & 1.91 & 1.48 & 1.26 & 1.43 & 1.75 & 1.71 & Groups & 12.00 & 10,688 & 0.031 \\
\hline \multirow[t]{2}{*}{15} & Training available off & Mean & 3.79 & 3.59 & 3.00 & 4.00 & 3.69 & 3.95 & 3.38 & 3.89 & 3.67 & 3.60 & 3.38 & Interaction & 0.81 & 10,688 & 0.628 \\
\hline & $\begin{array}{l}\text { campus on how to use } \\
\text { computer technologies } \\
\text { meets my needs }\end{array}$ & SD & 2.12 & 1.76 & 1.83 & 1.31 & 1.63 & 1.53 & 1.60 & 1.64 & 1.58 & 2.07 & 1.64 & & & & \\
\hline
\end{tabular}


Table 8. How well students' ICT-related needs are met at colleges and universities.

\begin{tabular}{|c|c|c|c|c|c|c|c|}
\hline & $\begin{array}{l}\text { School } \\
\text { type }\end{array}$ & $\mathrm{N}$ & Mean & SD & $t$ & df & Sig. \\
\hline \multicolumn{8}{|l|}{ Overall Criterion Items } \\
\hline In general, my computer technology & College & 358 & 5.10 & 1.31 & \multirow[t]{2}{*}{2.07} & \multirow[t]{2}{*}{1282} & \multirow[t]{2}{*}{0.039} \\
\hline needs at my school are adequately met & University & 926 & 4.93 & 1.34 & & & \\
\hline \multirow{2}{*}{$\begin{array}{l}\text { In general, my computer technology } \\
\text { needs at home are adequately met }\end{array}$} & College & 345 & 4.97 & 1.44 & \multirow[t]{2}{*}{0.14} & \multirow[t]{2}{*}{1268} & \multirow[t]{2}{*}{0.888} \\
\hline & University & 925 & 4.98 & 1.43 & & & \\
\hline \multicolumn{8}{|l|}{ POSITIVES Scale Subscales } \\
\hline Subscale 1 - ICTs at School Meet & College & 358 & 4.80 & 0.99 & \multirow[t]{2}{*}{3.24} & \multirow[t]{2}{*}{1287} & \multirow[t]{2}{*}{0.001} \\
\hline Student's Needs & University & 931 & 4.59 & 1.02 & & & \\
\hline Subscale 2 - ICTs at Home Meet Student's & College & 310 & 4.48 & 1.17 & \multirow[t]{2}{*}{1.83} & \multirow[t]{2}{*}{1101} & \multirow[t]{2}{*}{0.067} \\
\hline Needs & University & 793 & 4.33 & 1.22 & & & \\
\hline Subscale 3 - E-learning ICTs Meet & College & 348 & 5.09 & 0.86 & \multirow[t]{2}{*}{2.26} & \multirow[t]{2}{*}{1297} & \multirow[t]{2}{*}{0.024} \\
\hline Student's Needs & University & 951 & 4.97 & 0.84 & & & \\
\hline \multirow[t]{2}{*}{ POSITIVES Scale Total } & College & 368 & 4.87 & 0.85 & \multirow[t]{2}{*}{3.05} & \multirow[t]{2}{*}{1338} & \multirow[t]{2}{*}{0.002} \\
\hline & University & 972 & 4.71 & 0.86 & & & \\
\hline
\end{tabular}

on campus than those of university students. The same was true for e-learning-related ICT needs. There were no significant findings on ICTs for home use.

\section{Institution size}

Of course, total enrolments of junior/community colleges $(M=14,647$, median $=$ 10,000 , range $800-72,500$ ) were found to be considerably lower than those of universities $(M=32,723$, median $=25,500$, range $723-86,000)$. To explore whether institution size was related to how well students' needs were met, we correlated POSITIVES Scale Subscale and Total scores for the whole sample for university and junior/community college students separately. Pearson product moment correlation coefficients are all below 0.10 , suggesting that institution size, per se, is not related to how well students felt that their ICT-related needs are being met.

\section{Discussion}

\section{Key findings}

\section{Sample characteristics}

Consistent with others' findings, students with disabilities were somewhat older than typical post-secondary samples (mean age was 28), approximately half of the sample reported a learning disability (e.g. Stodden 2005), and 1/3 reported a psychological/psychiatric disability. This is not surprising given Blanco et al. (2008) findings showing that close to $50 \%$ of a large representative sample of American university students had a diagnosable psychiatric condition during a 12 month period.

It is noteworthy that over a third of our sample reported more than one disability, a finding similar to that reported in earlier investigations (e.g. Asuncion et al. 2002; 
Sharpe et al. 2005). This implies that ICTs need to be operable together and that conflicts between different adaptive technologies meant to support people with different disabilities need to be avoided.

\section{Students' academic programmes and disciplines}

The largest number of students were pursuing an undergraduate or a graduate degree or a junior/community college certificate or diploma. The findings also show that the largest proportion of participants were enrolled in the social sciences followed by arts and humanities and by science and engineering.

\section{What adaptive hardware andlor software do students use?}

Three quarters of the students in our sample indicated they used some form of specialised software and/or hardware. This suggests that a large proportion of students with disabilities on campus may need some type of adapted computer equipment. Overall, the findings indicate that more than $40 \%$ indicated using software to improve writing quality, such as grammar and spell checkers, followed in rank order of popularity, by software that reads what is on the screen, scanning and OCR, dictation software, and software that enlarges what is on the screen.

However, the number of students with different disabilities varies in the sample, and the very large number of students with learning disabilities, psychological/ psychiatric impairments and multiple disabilities can skew the results. Therefore, we also note below the computer technologies mentioned by a minimum of $15 \%$ of students in each disability grouping:

(1) Learning disability/ADD/ADHD: software that improves writing quality, software that reads what is on the screen, scanning and OCR, dictation software. Except for software that improves writing quality, these technologies traditionally are considered to be useful primarily for students with visual and neuromuscular impairments (Ofiesh et al. 2002)

(2) Totally blind: software that reads what is on the screen, scanning and OCR, refreshable Braille display, software that improves writing quality

(3) Low vision: software that enlarges what is on the screen, software that reads what is on the screen, large screen monitor, software that improves writing quality, scanning and OCR

(4) Deaf: software that improves writing quality, scanning and OCR

(5) Hard of hearing: software that improves writing quality

(6) Mobility impairment: software that improves writing quality

(7) Limited use of hands or arms: software that improves writing quality, dictation software, alternative mouse, adapted keyboard

(8) Medically related/health problem: software that improves writing quality, software that enlarges what is on the screen

(9) Psychological/psychiatric disability: software that improves writing quality

(10) Neurological impairment: software that improves writing quality, dictation software

(11) PDD: software that improves writing quality 


\section{C.S. Fichten et al.}

\section{How well are students' ICT-related needs being met?}

Findings on POSITIVES Scale Subscales indicate that, overall, students' e-learningand ICT-related needs on campus are better met than their ICT-related needs at home. Consistent with data from other researchers (Sharpe et al. 2005), our results show more favourable than unfavourable scores. Nevertheless, there are some concerns around funding for computer technologies for personal use as well as around training, both on and off campus. This was also the case for technical support when the student is not on campus. Availability of computers with adaptive software/ hardware in the institution's specialised computer laboratories and institutional computer technology loan programmes also had relatively low scores. Accessibility of computers in campus computer labs has been noted as an issue of concern by students going back to the 1990s (e.g. Armstrong et al. 1997).

Difficulties with institutional loan programmes can result in students losing a semester. When their computer or expensive adaptive software fails, students are not able to do their work at home. In many cases, they cannot do their work on campus either, since many students use their laptops with adaptive software to take notes and follow in-class assignments. If there are also limited numbers of computers with needed adaptive software or hardware in the institution's computer labs, students are truly disadvantaged. Because it can take several weeks to have malfunctioning computers repaired, especially those with adaptive software or hardware, good laptop loan programmes are needed. Many of us have seen students lose a semester because of balky computers and inadequate or non-existent loan programmes.

It was encouraging to find that institutions' web pages were seen as accessible; students felt they were able to use the computer technologies they needed; campuses had experts who could deal with adaptive technologies; electronic text versions of course materials were available; and interactive online services and the library's computer systems were generally quite accessible.

\section{Students with different disabilities}

Overall, the findings suggest that the ICT-related needs of students in all groups are met relatively well. Nevertheless, the needs of students who are totally blind, those with multiple disabilities, and those with low vision were met least adequately. The needs of students who are hard of hearing and who have a medically related/health problem, a mobility impairment or a psychological/psychiatric disability were met most effectively.

\section{Home versus campus}

Findings on POSITIVES Scale Subscales suggest that while this pattern is true for how well e-learning- and ICT-related needs are met on campus, the pattern of results is very different for home use, where the ICT-related needs of the following groups were met least well: multiple disabilities, psychological/psychiatric disability and learning disability/ADD/ADHD. Home- based ICT-related needs of students with a mobility impairment, those who are hard of hearing and those who are totally blind were being met best.

To explore differences between campus and home we compared the views of students with different disabilities about how well their ICT-related needs were being 
met in three contexts: (1) ICTs sufficiently up-to-date, (2) technical support needs met, (3) training needs met. The results show that (1) students' technical support as well as training needs were better met on campus than at home; (2) students who were totally blind felt that their technologies were more up-to-date at home than on campus; (3) students with learning disabilities and medically and psychologically related and multiple disabilities felt their ICTs were more up-to-date on campus than at home.

Such findings suggest that colleges and universities need to ensure that they install the latest versions of adaptive software. Particular attention needs to be paid to ICTs for students with visual impairments. Needless to say, all students must be able to have up-to-date technologies at home available to them as well. Additional assistance with funding for ICTs would be beneficial in this regard.

\section{Junior/community colleges versus universities}

The findings also show that junior/community college students' ICT-related needs were better met on campus than those of university students. The same was true for e-learning-related ICT needs, although there were no significant findings for home use. While it was possible that campus size could account for this finding, our results conclusively show that institution size, be it for colleges or universities, is not related to how well students feel that their ICT-related needs are being met. Of course, the findings may be accounted for by better availability, accessibility or usability of ICT in colleges. Alternately, colleges may use ICTs less extensively than universities. This is an empirical question that needs further investigation.

\section{Limitations}

It should be noted that our sample is neither random nor fully representative of the populations studied. First, students self-identified as having a disability. Second, given the nature of participant recruitment and self-selection biases, students who read online discussion lists, had experience using e-learning, or were highly experienced ICT users are simply over-represented. Especially troubling is that calculating a "return rate" was impossible because of the manner in which participants were recruited. It should also be noted that when we compared scores of students with different disabilities the sample sizes differ greatly. This resulted in some ANOVA tests that were non-orthogonal due to unequal and a disproportionate $n$, and these results should be interpreted with some caution. On the positive side, the sample size is large, and most available indices suggest that participants have characteristics that are typical of Canadian post-secondary education.

\section{Implications for future research and practice}

The findings highlight the idea that ICTs which meet the needs of students with disabilities involve widespread availability of ICTs with adaptive software/hardware in both specialised and general use labs on campus, good support for these technologies, the availability of training on ICTs, available ICTs for home use, as well as accessible campus computing infrastructure and e-learning used by faculty.

To support the academic success of students with disabilities, we recommend that colleges and universities, along with rehabilitation professionals and educators, 


\section{C.S. Fichten et al.}

identify and assess what ICT training and equipment they provide to students and act upon any gaps, especially those identified by the students themselves. Students, of course, need to be proactive in managing their own learning experiences.

Possible research directions include continued validation of the POSITIVES Scale by administering the measure to samples outside Canada, by comparing scores of non-disabled students with those of students with different disabilities, and by examining links between POSITIVES Scale scores and student satisfaction persistence, and engagement.

We suggest that colleges and universities use the POSITIVES Scale to conduct digital accessibility audits. This could allow them to assess modifiable aspects of the accessibility, usability and availability of ICTs both on and off campus as well as permit monitoring and evaluation of the effects of efforts to improve meeting students' needs. As ICTs and e-learning evolve, attention will be needed to pay to accessibility and usability issues related to tablet computers, SmartPhones and any new ICTs that are used to facilitate teaching and learning.

The results also point the way towards the types of changes colleges and universities could make to enhance digital inclusion of students with disabilities. For example, they could ensure: that adaptive technologies on campus are up-to-date, that they provide students, whose personal ICTs fail, access to loans of laptops/ tablets with needed adaptive technologies, that there are workshops and other opportunities for students with disabilities to learn to use needed ICTs and that ICT help lines have at least minimal information to assist students with adaptive technologies. Of course, faculty could be encouraged to use universal design. Although this would not replace the need for adaptive computer technologies, it could go a long way to improving digital access while saving money. For example, a disability service provider recently noted that since professors started to post their notes online, the cost of note takers for students with disabilities at her college dropped dramatically (S. Wileman, November, 2011).

Universal instructional design (McGuire, Scott, and Shaw 2003; Scott, McGuire, and Foley 2003), which proposes using instructional strategies and products that are usable by all students whenever possible, without the need for specialised adaptations, would go a long way towards removing access problems. Proponents of this concept hold that if something works well for people with disabilities, it generally works better for everyone (Barile, Nguyen, and Fichten 2012; Shaw 2002). Burgstahler's (2012) brochures, as well as the excellent book edited by Burgstahler and Cory (2008), provide suggestions for implementing universal instructional design in the postsecondary environment.

For example, professors could ensure that they post their course notes online at least a week in advance. This would allow students with visual, hearing and learning disabilities to come prepared for class. Of course, this would also allow ALL students to come prepared. Given the extensive use of scanning and OCR by students with all types of disabilities, computer labs should be equipped with scanners. Of course, scanning would also allow students with and without disabilities to use their laptops or tablets more effectively since there would be a diminished need to carry paper. This could also facilitate another universal instructional design procedure - allowing students to submit assignments online. Because of their medical situation or an inaccessible campus, some students have difficulty getting to the professor's office hours. Digital office hours could provide a solution for them, thereby also allowing 
students without disabilities who cannot get to the professor's office because of climate, a job or transportation difficulties better access.

Recently, both American (Office For Civil Rights 2011) and some Canadian governments (Ontario 2009) reiterated the need for accessibility of ICTs in postsecondary education. Ensuring that the ICT-related needs of students with all types of disabilities are being met needs to become a priority for colleges, universities, tutoring centres and rehabilitation facilities. This will result in fewer ICT-related needs being unmet (on campus, at home, and in the context of interacting with e-learning), contribute to the removal of barriers and equip students with disabilities with the skills needed to succeed in the increasingly ICT-driven world of study, work, community and leisure.

\section{Acknowledgements}

This research was funded by the Canadian Council on Learning. We are grateful for the support.

\section{References}

Abrami, P. C., et al., (2006) 'A review of e-learning in Canada: a rough sketch of the evidence, gaps and promising directions', Canadian Journal of Learning and Technology, vol. 32, no. 3, [online] Available at: http://www.cjlt.ca/index.php/cjlt/article/view/27/25

Armstrong, W. B., et al., (1997) Americans with Disabilities Act (ADA): City College SelfEvaluation Study, San Diego Community College District, San Diego.

Asuncion, J. V., et al., (2002) 'Dialoguing with developers and suppliers of adaptive computer technologies: data and recommendations', Universal Access in the Information Society, vol. 1, no. 3, pp. 177-196.

Barile, M., Nguyen, M. N. \& Fichten, C. S. (2012) 'L'accessibilité universelle en pédagogie: des avantages pour toutes et tous!', Pédagogie Collégiale, vol. 25, no. 4, pp. 20-22.

Blanco, C., et al., (2008) 'Mental health of college students and their non-college-attending peers results from the national epidemiologic study on alcohol and related conditions', Archives of General Psychiatry, vol. 65, no. 12, pp. 1429-1437.

Boudreau, D. (2011) 'Social media accessibility: where are we today?', AccessibilitéWeb, [online] Available at: http://accessibiliteweb.com/presentations/2011/a11yBOS/\#1

Burgstahler, S. (2012) 'Universal design of instruction (UDI): definition, principles, guidelines, and examples', [online] Available at: http://www.washington.edu/doit/Brochures/PDF/ instruction.pdf

Burgstahler, S. \& Cory, R. C., eds. (2008) Universal Design in Higher Education: From Principles to Practice, Harvard Education Press, Cambridge.

CDW-G (2011) 'The 2011 CDW-G 21st-century campus report', [online] Available at: http://webobjects.cdw.com/webobjects/media/pdf/newsroom/CDWG-21st-CenturyCampusReport-0711.pdf

Fichten, C. S., et al., (2009a) 'Accessibility of e-learning, computer and information technologies to students with visual impairments in postsecondary education', Journal of Visual Impairment and Blindness, vol. 109, no. 9, pp. 543-557.

Fichten, C. S., et al., (2009b) 'Disabilities and e-learning problems and solutions: an exploratory study', Educational Technology and Society, vol. 12, no. 4, pp. 241-256.

Fichten, C. S., et al., (2010) 'The POSITIVES Scale: development and validation of a measure of how well the information and communication technology needs of students with disabilities are being met', Journal of Postsecondary Education and Disability, vol. 23, no. 2, pp. $137-154$.

Holmes, D. (2005) Embracing Differences: Post-Secondary Education among Aboriginal Students, Students with Children and Students with Disabilities, The Canadian Millennium Scholarship Foundation, Ottawa.

Martiniello, N., et al., (2008) Disciplines Coding Manual for College and University Studies, Adaptech Research Network, Montreal. 


\section{C.S. Fichten et al.}

McGuire, J. M., Scott, S. S. \& Shaw, S. F. (2003) 'Universal design for instruction: the paradigm, its principles, and products for enhancing instructional access', Journal of Postsecondary Education and Disability, vol. 17, no. 1, pp. 10-20.

Media Access Australia. (2012) 'Sociability: social media for people with a disability', CSUN'S 27th Annual International Technology and Persons with Disabilities Conference, San Diego, CA, [online] Available at: accan.org.au/files/Reports/Sociability\%20Report.pdf

Office for Civil Rights. (2011) Frequently Asked Questions about the June 29, 2010, Dear Colleague Letter, US Department of Education, Washington, [online] Available at: http:// www2.ed.gov/print/about/offices/list/ocr/docs/dcl-ebook-faq-201105.html

Ofiesh, N. S., et al., (2002) 'Service delivery for postsecondary students with disabilities: a survey of assistive technology use across disabilities', College Student Journal, vol. 36, no. 1, pp. 94-108.

Ontario. (2009) 'Accessibility for Ontarians with Disabilities Act (AODA)', [online] Available at: http://www.e-laws.gov.on.ca/html/statutes/english/elaws_statutes_01o32_e.htm\#

Raue, K. \& Lewis, L. (2011) Students with Disabilities at Degree-Granting Postsecondary Institutions: First Look (NCES 2011-018), U.S. Department of Education, National Center for Education Statistics, Washington, [online] Available at: http://nces.ed.gov/ pubs2011/2011018.pdf

Scott, S. S., McGuire, J. M. \& Foley, T. E. (2003) 'Universal design for instruction: a framework for anticipating and responding to disability and other diverse needs in the college classroom', Equity and Excellence in Education, vol. 36, no. 1, pp. 40-49.

Seale, J., Draffan, E. A. \& Wald, M. (2008) Exploring Disabled Learners' Experiences of E-Learning, LEXDIS Project Report, University of Southampton, [online] Available at: http://eprints.soton.ac.uk/64850/1/LEXDIS_ProjectReport_Dec08.pdf

Sharpe, M. N., et al., (2005) 'An analysis of instructional accommodations and assistive technologies used by postsecondary graduates with disabilities', Journal of Vocational Rehabilitation, vol. 22, no. 1, pp. 3-11.

Shaw, S. F. (2002) Postsecondarys Supports for Students with Disabilities, National Capacity Building Institute, Honolulu, HI, pp. 26-28.

Stodden, R. A. (2005) 'Supporting persons with disabilities in postsecondary education and life long learning', Journal of Vocational Rehabilitation, vol. 22, pp. 1-2. 